\title{
Effects on Motor Development and Performance Levels of Physical Activity in Music Accompaniment on Children with Developmental Deficiencies
}

\author{
Songül Pektaş' ${ }^{1} \&$ Betül Akyol ${ }^{2}$ \\ ${ }^{1}$ Amasya University, Facultyof Education, Turkey \\ ${ }^{2}$ Inonu University, Faculty of Sport Sciences, Turkey \\ Correspondence: Betül Akyol, Inonu University, Faculty of Sport Sciences, Turkey.
}

Received: September 29, 2018

Accepted: October 30, $2018 \quad$ Online Published: October 31, 2018

doi:10.11114/jets.v6i12a.3743

URL: https://doi.org/10.11114/jets.v6i12a.3743

\begin{abstract}
The aim of this study was to investigate the effects of physical activity with music on motor development and performance in children with developmental deficiencies. The study includes twenty children with developmental deficiencies, aged between 10-15 years old. Children were classified into two groups randomly and both groups were given 1 hour of training 3 days a week for 20 weeks. Physical activity with English and Spanish verbal song was used for the first group and only physical activity for the second group. Each participant participated in shuttle, shuttle run, flexibility, standing long jump, vertical jump tests. The fatigue parameter of children was evaluated using the Visual Analog Scale. As a result of this study, it has been shown that physical activity with music is more effective method to improve motor development and performance levels of children with developmental deficiencies.
\end{abstract}

Keywords: physical activity, music, developmental deficiencies

\section{Introduction}

Developmental deficiency is a major cause of mental and motor disability that indicates the differences in mental, emotional, physical, social or communicational characteristics of an individual (Kurcaali-İftar, 2002). These disabilities lead to considerable functional limitations in three or more of the basic life activities such as self-care, receptive and expressive language, learning, mobility, self-management, economic competence and independent living ability. Individuals with various genetic and chromosomal disorders such as mental deficiency, Cerebral Palsy, Autism Spectrum disorder, Down Syndrome, Fragile X Syndrome and Fetal Alcohol Spectrum Disorder are explained as "developmental disability". Mental impairment and Autism Spectrum disorder can be expressed as the most prominent groups (APA, 2013). Individuals with developmental disabilities appear to be more or less dependent on someone else to lead in many cases in their daily lives (Farlow and Snell, 2003). Whatever the level and type of disability of children with developmental disability, the most basic goal is to achieve independent living skills. Independent living skills are a concept to meet all of the needs beyond the primary requirements of nutrition, shelter and love that are necessary for the individual to continue his / her life from birth and in general, it can be classified as basic skills, adaptive skills, daily living skills and professional skills (Cavkaytar, 2000). Independent living skills consist of gross motor skills, fine motor skills and balance development. In children with developmental deficiencies, physical activity for skill and balance development is important. It is vital for children with developmental deficiencies to use effective and efficient teaching methods during the teaching of academic and developmental skills (Tekin-İftar and Kırcaali-İftar, 2006). Music provides children's attention to use his/her fine motor skills, beginning with the gross motor skills, to learn to recognize and use the child's body. It has been shown that the human musculoskeletal system can be improved by music and rhythm instruments (Toksoy and Başar, 2017).

Physical activity training is known to have positive effects on motor development and performance levels in children with developmental deficiencies. There are not enough studies about the effect of music-based physical activity training on motor development and performance levels in such children.

It is important that physical activity can be performed simultaneously with music accompanied by tempo. There are not enough studies on the effect of music-based physical activity training on motor development and performance levels in 
children with developmental deficiencies. This study was planned to investigate the effect of music-based physical activity training on motor development and performance levels in children with developmental deficiencies aged 10-15 years, taking into account the positive effects of music and physical activity on the human body.

\section{Method}

The study includes twenty children with developmental deficiencies, participated in the project "Every child succeeds if you give a chance" that the governor of Malatya started to work. Twenty children with developmental deficiencies aged between 10-15 years old in the study. A voluntary consent form was obtained from the participants' parents before the study. Children were classified into two groups randomly and both groups were given 1 hour of training 3 days a week for 20 weeks. Physical activity with music "Chocolate song (Choko Choko)" was used for the first group and only physical activity for the second group. Physical activity consisted of shuttle, kicking, throwing, rolling the ball and catching the ball by hand, slalom, jumping, long jump by standing, vertical jumping, stretching and shuttle run. By using the motivating effect of a fast-paced and enthusiastic song in children's physical activity training with music group; was chosen an English and Spanish verbal song with a 4/4 rhythm pattern that is believed to be reproducible, moving and more memorable. The number of each movement is increased by certain periods. Each movement; $1 \mathrm{st}$ and 4th week 10 times, 5th and 8th week 15 times, 9th and 12th week 20 times, 13th and 16th week 20 times, 17th and 20th week 20 times were done. Each participant performed shuttle, shuttle run, flexibility, standing long jump, vertical jump test measurements to determine motor development level and performance level as pre- and post-test. In addition, Visual Analog Scale (VAS) was used to evaluate the level of pain. A score of 0 was defined as no pain while a score of 10 as intolerable pain.

\subsection{Shuttle}

Participant was laid on his back, the hand glued, the body was held tight, his feet were held in united condition, and he was told to straighten his body forward without receiving support and recorded how many times he did (Biçer, Savucu, Kutlu, Kaldirimci and Pala, 2004).

\subsection{Shuttle Run Test}

A calibrated cassette with $0.5 \mathrm{~km} / \mathrm{h}$ increased every minute of signal intervals was used. The children were asked to touch the line at the end of $20 \mathrm{~m}$ in each signal. When the signal arrives, the test is terminated for the child who cannot reach two meters above the line in front of one meter of the lines that determine $20 \mathrm{~m}$ (Ayan and Mülazımoğlu,2010).

\subsection{The Sit-and-Reach Test}

Child sat on the floor with the legs extended, shoulder width apart, and feet flat against the box. The participant slowly slid his/her hands across the top of a ruler attached to the top of the box until maximum reach was attained. The participant completed three reaches and the best reach was recorded. Measurements were recorded to the 25 inches and converted to centimetres for analysis (Jackson et al., 1998).

\subsection{Standing Long Jump Test}

A line was drawn on the floor where the long jump test was to be stopped. The child is standing upright behind the line. $\mathrm{He} / \mathrm{she}$ jumps forward on the ground and touch of their feet and the distance of the heel and line was measured as $\mathrm{cm}$ (Biçer, Savucu, Kutlu, Kaldirimci and Pala, 2004).

\subsection{Vertical Jump Test}

Participants tried to jump as high as possible with double leg near the wall. Before the test, the child's normal arm length was determined alongside the wall. He/she jumps vertically alongside the wall and difference between the jump distance and arm length was determined. Vertical jump distance was done twice and the best result was recorded as cm (Ayan and Mülazımoğlu, 2010).

\subsection{VAS (Visual Analogue Scale)}

Each participant was asked whether they had fatigue in the extremity and to mark the severity of pain on a 0-10 scale (Nicklin et al., 2010).

\section{Data Analyses}

The level of performance parameters were assessed pre and post-test using dependent $\mathrm{T}$ test and Independent $\mathrm{t}$ for within groups. Data were analyzed using IBM-SPSS Statistics 22.0 software. A value of $\mathrm{p}<0.05$ was accepted as statistically significant. 


\section{Results}

Table 1. All participants pre-test motoric and performance parameters

\begin{tabular}{|c|c|c|c|c|c|c|}
\hline & & $\mathbf{N}$ & M.A & S.D & $\mathbf{T}$ & p \\
\hline \multirow[t]{2}{*}{ Shuttle } & 1. Group & 10 & 10.74 & 3.02 & \multirow[t]{2}{*}{6.122} & \multirow[t]{2}{*}{0.123} \\
\hline & 2. Group & 10 & 11.38 & 2.06 & & \\
\hline \multirow[t]{2}{*}{ Shuttle run } & 1. Group & 10 & 13.03 & 1.92 & \multirow[t]{2}{*}{-5.133} & \multirow[t]{2}{*}{0.234} \\
\hline & 2. Group & 10 & 12.07 & 1.84 & & \\
\hline \multirow[t]{2}{*}{ Sit-reach } & 1. Group & 10 & 8.72 & 0.69 & \multirow[t]{2}{*}{2.121} & \multirow[t]{2}{*}{0.363} \\
\hline & 2. Group & 10 & 8.67 & 0.14 & & \\
\hline \multirow[t]{2}{*}{ Vertical jump test } & 1. Group & 10 & 8.07 & 2.12 & \multirow[t]{2}{*}{1.223} & \multirow[t]{2}{*}{0.143} \\
\hline & 2. Group & 10 & 8.23 & 2.43 & & \\
\hline \multirow[t]{2}{*}{ Standing long jump } & 1. Group & 10 & 23.45 & 3.54 & \multirow[t]{2}{*}{1.432} & \multirow[t]{2}{*}{0.232} \\
\hline & 2. Group & 10 & 24.12 & 2.89 & & \\
\hline \multirow[t]{2}{*}{ VAS } & 1. Group & 10 & 7.12 & 1.01 & \multirow[t]{2}{*}{1.321} & \multirow[t]{2}{*}{0.111} \\
\hline & 2. Group & 10 & 8.02 & 1.23 & & \\
\hline
\end{tabular}

M.A.: arithmetic mean, S.D: standard deviation, VAS: visual analogue scale

There was no statistically significant difference between the 1st and 2nd groups according to the results of tests $(\mathrm{p}>0.05)$.

Table 2. All participants post- test motoric and performance parameters

\begin{tabular}{|c|c|c|c|c|c|c|}
\hline & & $\mathbf{N}$ & A.M. & S.D & $\mathbf{T}$ & $\mathbf{p}$ \\
\hline \multirow[t]{2}{*}{ Shuttle } & 1. Group & 10 & 28.69 & 3.84 & \multirow[t]{2}{*}{-7.112} & \multirow[t]{2}{*}{$0.001 *$} \\
\hline & 2. Group & 10 & 19.52 & 3.21 & & \\
\hline \multirow[t]{2}{*}{ Shuttle run } & \multirow{2}{*}{$\begin{array}{l}\text { 1. Group } \\
\text { 2. Group }\end{array}$} & 10 & 31.06 & 1.98 & \multirow[t]{2}{*}{-6.511} & \multirow[t]{2}{*}{$0.001 *$} \\
\hline & & 10 & 21.22 & 1.22 & & \\
\hline \multirow[t]{2}{*}{ Sit-reach } & 1. Group & 10 & 23.53 & 0.93 & \multirow[t]{2}{*}{-5.482} & \multirow[t]{2}{*}{$0.001 *$} \\
\hline & 2. Group & 10 & 12.62 & 0.23 & & \\
\hline \multirow[t]{2}{*}{ Vertical jump } & 1. Group & 10 & 23.907 & 0.565 & \multirow[t]{2}{*}{-6.231} & \multirow[t]{2}{*}{$0.001 *$} \\
\hline & 2. Group & 10 & 18.807 & 0.936 & & \\
\hline \multirow{2}{*}{ Standing long jump } & 1. Group & 10 & 38.67 & 3.23 & \multirow[t]{2}{*}{-5.122} & \multirow[t]{2}{*}{$0.001 *$} \\
\hline & 2. Group & 10 & 30.12 & 2.42 & & \\
\hline \multirow[t]{2}{*}{ VAS } & 1. Group & 10 & 2.12 & 0.12 & \multirow[t]{2}{*}{3.232} & \multirow[t]{2}{*}{$0.001 *$} \\
\hline & 2. Group & 10 & 5.34 & 0.34 & & \\
\hline
\end{tabular}

M.A.: arithmetic mean, S.D: standard deviation, VAS: visual analogue scale, $(* \mathrm{p}<0.05)$

Statistically significant differences were observed between the first and second groups according to the post-operative evaluations: Shuttle, Shuttle run, sit-reach, vertical jump, standing long jump, VAS parameters $(\mathrm{p}<0.05)$. 
Table 3. Group 1 motoric and performance parameters of pre and post test

\begin{tabular}{lllllll}
\hline Shuttle & & N & M.A. & S.D & T & p \\
& Before & 10 & 10.74 & 3.02 & 6.451 & $0.001^{*}$ \\
& After & 10 & 28.69 & 3.84 & & \\
\hline Shuttle run & Before & 10 & 13.03 & 1.92 & 5.625 & $0.001^{*}$ \\
& After & 10 & 31.06 & 1.98 & & \\
\hline Sit-reach & Before & 10 & 8.72 & 0.69 & 3.142 & $0.001^{*}$ \\
& After & 10 & 23.53 & 0.93 & & \\
\hline Vertical jump test & Before & 10 & 8.07 & 2.12 & 2.458 & $0.001^{*}$ \\
& After & 10 & 23.90 & 0.56 & & $0.001^{*}$ \\
\hline Standing long jump & Before & 10 & 23.45 & 3.54 & 4.654 & \\
& After & 10 & 38.67 & 3.23 & & $0.001^{*}$ \\
\hline VAS & Before & 10 & 7.12 & 1.01 & 4.125 & \\
\hline
\end{tabular}

MA: arithmetic mean, S.D: standard deviation, VAS: visual analogue scale, $(* p<0.05)$

Statistically significant differences were observed in Shuttle, Shuttle run, sit- reach, vertical jump, standing long jump, VAS parameters in pre and post-test of first group $(\mathrm{p}<0.05)$.

Table 4. Group 2 motoric and performance parameters pre and post test

\begin{tabular}{lllllll}
\hline Shuttle & & N & M.A. & S.D & T & p \\
& Before & 10 & 14.38 & 2.06 & 4.689 & $0.001^{*}$ \\
& After & 10 & 20.52 & 3.21 & & \\
\hline Shuttle run & Before & 10 & 12.07 & 1.84 & 5.454 & $0.001^{*}$ \\
& After & 10 & 21.22 & 1.22 & & $0.001^{*}$ \\
\hline Sit-reach & Before & 10 & 8.67 & 0.14 & 5.212 & \\
& After & 10 & 12.62 & 0.23 & & $0.001^{*}$ \\
Vertical jump test & Before & 10 & 8.23 & 2.43 & 6.521 & $0.001^{*}$ \\
& After & 10 & 18.80 & 0.93 & & \\
\hline Standing long jump & Before & 10 & 24.12 & 2.89 & 3.124 & $0.001^{*}$ \\
& After & 10 & 30.12 & 2.42 & & 2.145 \\
\hline VAS & Before & 10 & 8.02 & 1.23 & & \\
& After & 10 & 5.34 & 0.34 & & \\
\hline
\end{tabular}

M.A.: arithmetic mean, S.D: standard deviation, VAS: visual analogue scale, $\left({ }^{*} \mathrm{p}<0.05\right)$

Statistically significant differences were observed in Shuttle, Shuttle run, sit- reach, vertical jump, standing long jump, VAS parameters of pre and post -test in the second group $(\mathrm{p}<0.05)$.

\section{Discussion}

The aim of this study was to investigate the effect of physical activity with music on motor development and performance levels of children with developmental deficiencies. Statistically significant differences were observed between the first group and the second group according to the evaluations performed after the study, in Shuttle, Shuttle run, sit-reach, vertical jump, standing long jump test and VAS parameters $(\mathrm{p}<0.05)$. Although there was an increase in the parameters of Shuttle, Shuttle run, sit-reach, vertical jump, and standing long jump test and decrease in VAS values in both groups, statistically significant differences were observed between comparisons groups $(\mathrm{p}<0.05)$.

Physical activity in music accompaniment enhances performance and motoric activities, including long-distance 
running, walking, rowing. The extent of musical engagement and its nature will be a factor in the extent to which transfer can occur to other areas. It explores evidence relating to impact of musical skills on language development, fine motor coordination, concentration, self-confidence, emotional sensitivity, social skills, and relaxation. This has implications for quality of teaching. The brain develops in very specific ways in response to particular learning activities and extent of change depends on length of time engaged with learning. The extent of musical engagement and its nature will be a factor in the extent to which transfer can occur to other areas (Hallam, 2010).

In a study done by Cynthia Tam et al., six children with severe physical disabilities, aged between 2.6 and 7 years participated. They use the movement-to-music (MTM). This system is an affordable computer one that allows children with limited movements to play and create music. Each child attended a weekly, individual session at the rehabilitation centre, for $6-8$ weeks. At the end of the study each children have seen improving psycho-social skills, improving body function (Tam et al., 2007).

The role of music in facilitating language skills contributes to the development of reading skills. In the other study; where music instruction was specifically designed to develop auditory, visual and motor skills in 7-10 year-old children over a period of six months, found that the mean reading comprehension scores of the intervention group increased while the control group did not. Results indicate that musical skill training is a valuable strategy for assisting children with reading difficulties (Douglas and Willatts, 1994).

Other research has reported Peripatetic instrumental teachers working in schools considerable benefits of learning to play an instrument, including the development of social skills; developing a sense of achievement, confidence and self-discipline; and developing physical coordination (Hallam and Prince, 2000).

Anshel and Marisi (1978) observed positive results in performance accuracy and endurance when music was rhythmically synchronized with motor performance. Music with physical tasks is associated with enhanced performance or increased work output (Anshel and Marisi, 1978).

It is observed that songs with faster tempos and strong rhythms are expected to activate the sympathetic nervous system and enhance performance (Belford, Neher, Pernsteiner and Stoffregen, 2013)

The other study is applying music with athletes and exercise participants highlight the importance for practitioners to be conversant with the potential benefits of music in order to tap its psychophysical and ergogenic properties with precision (Terry and Karageorghis, 2006)

Music training initiated between the ages of five and seven leads to cognitive enhancement and stimulates regional brain growth in areas previously shown to be structurally different in adult musicians. It is shown that learning to play an instrument improves fine motor skills, auditory discrimination skills. Because the tasks of reading music and playing an instrument call upon a wide variety of skills, there are plausible explanations for why music training could lead to transfer effects in other areas (Schlaug, Norton, Overy and Winner, 2005).

This study was supported by studies in the literature, showed that motor development and performance levels in children with developmental deficiencies receiving physical activity training are common. However, the result is that physical activity in music accompaniment is more effective in increasing motor development and performance levels.

As a result, physical activity with music accompaniment in children with developmental deficiencies was found to have a motivating effect on children and at the same time, it makes the abdomen, back, leg muscles more active and suppresses the child's tiredness, which is why the children are more willing to achieve the goal.

\section{Declaration of Conflicting Interests}

The author(s) declared no potential conflicts of interest with respect to the research, authorship, and/or publication of this article.

\section{References}

Anshel, M., \& Marisi, D. (1978). Effect of music and rhythm on physical performance. Research Quarterly, 49, $109-113$.

APA, (2013). Diagnostic and statistical manual of mental disorders, 5th edition (DSM 5). Washington, DC, American Psychiatric Association.

Ayan, V., \& Mülazımoğlu, O. (2010). Sporda yetenek seçimi ve spora yönlendirmede 8-10 yaş grubu kız çocuklarinin fiziksel özelliklerinin ve bazı performans profillerinin incelenmesi (Ankara örneği). Nigde University Journal of Physical Education and Sport Sciences, 4(3), 152-159.

Belford, Z. Neher, C., Pernsteiner, T., Stoffregen, J., \& Tariq, Z. (2013). Music \& Physical Performance: The effects of different music genres on physical performance as measured by the heart rate, electrodermal arousal and maximum 
grip strength. Journal of Advanced Student Science (JASS), 1, 1-11.

Biçer, Y., Savucu, Y., Kutlu, M., Kaldirimci, M., \& Pala, R. (2004). Güç ve kuvvet egzersizlerinin zihinsel engelli çocuklarin hareket beceri ve yeteneklerine etkisi. F.Ü. Doğu Anadolu Bölgesi Araştırmaları Dergisi, 3(1), 173-179.

Cavkaytar, A. (2000). Zihinsel yetersizliği olanların eğitim amaçları. Anadolu Üniversitesi Eğitim Fakültesi Dergisi, $10(1)$.

Douglas, S., \& Willatts, P. (1994). The relationship between musical ability and literacy skills. Journal of Research in Reading, 17(2), 99-107. https://doi.org/10.1111/j.1467-9817.1994.tb00057.x

Farlow, L. J., \& Snell, M. E. (2003). Teaching basic self-care skills. M. Snell \& F. Brown (Ed.) Instructionof Students with Severe Disabilities. (331-377). Ohio: Merill Prentice Hall, Colombus.

Hallam, S., \& Prince, V. (2000). Research into instrumental music services. London: dfee.

Hallam, S. (2010). The power of music: Its impact on the intellectual, social and personal development of children and young people. International Journal of Music Education, 28(3), 269-289. https://doi.org/10.1177/0255761410370658

Jackson, A.W., Morrow, J. R., Brill, P. A., Kohl, H. W., Gordon, N. F., \& Blair, S. N. (1998). Relations of sit-up and sit-and-reach tests to low back pain in adults. J Orthop Sports Phys Ther. Jan;27(1), 22-26.

Kırcaali-İftar, G. (2002). İleri Derecede ve Çoklu Yetersizlikler. Özel eğitim. Eskişehir: Anadolu Üniversitesi AÖF Yayınları.

Nicklin, J., Cramp, F., Kirwan, J., Greenwood, R., Urban, M., \& Hewlett S. (2010). Measuring fatigue in rheumatoid arthritis: a cross-sectional study to evaluate the Bristol Rheumatoid Arthritis Fatigue Multi-Dimensional questionnaire, Visual analog scales, and numerical rating scales. Arthritis Care Res (Hoboken). Nov;62(11), 1559-1568. https://doi.org/10.1002/acr.20282

Schlaug, G., Norton, A., Overy, K., \& Winner, E. (2005). Effects of music training on the child's brain and cognitive development. Annals of the New York Academy of Science, 1060, 219-230. https://doi.org/10.1196/annals.1360.015

Tam, C., Schwellnus, H., Eaton, C., Hamdani, Y., Lamont, A., \& Chau, T. (2007). Movement-to-music computer technology: a developmental play experience for children with severe physical disabilities. Occupational therapy international, 14(2), 99-112. https://doi.org/10.1002/oti.227

Tekin-İftar, E., \& Kırcaali-İftar, G. (2006). Özel eğitimde yanlışsız öğretim yöntemleri (3.Bask1). Ankara: Nobel Yayıncilik.

Terry, P. C., \& Karageorghis, C. I. (2006). Psychophysical effects of music in sport and exercise: an update on theory, research and application. In: Psychology Bridging the Tasman: Science, Culture and Practice, 26-30 Sep, Auckland, New Zealand.

Toksoy, A. C., \& Başar, Ş. (2017). 6-12 yaş orta-ağır zihinsel yetersizliği olan çocuklar için ritim uygulamaları. Abant İzzet Baysal Üniversitesi Eğitim Fakültesi Dergisi, 17(1), 384-399.

https://doi.org/10.17240/aibuefd.2017.17.28551-304642

\section{Copyrights}

Copyright for this article is retained by the author(s), with first publication rights granted to the journal.

This is an open-access article distributed under the terms and conditions of the Creative Commons Attribution license which permits unrestricted use, distribution, and reproduction in any medium, provided the original work is properly cited. 